\title{
Gitelman Syndrome Presenting with Hypomagnesemia, Hypokalemia and Hypocalciuria: A Case Report
}

\section{Hipomagnezemi, Hipokalemi ve Hipokalsiüri ile Başvuran Gitelman Sendoromu: Olgu Sunumu}

\section{Mehmet UZUNLULU ๑, Betul DUMANOGLu ๑}

Ethics Committee Aproval: Not Applicable.

Confillict of Interest: The authors declare that they have no conflict of interest.

Funding: None.

Informed Concent: Informed consent was taken.
Cite as: Uzunlulu M, Dumanoglu B. Gitelman syndrome presenting with hypomagnesemia, hypokalemia and hypocalciuria - A case report. Medeniyet Med J. 2019;34:314-7.

\begin{abstract}
Gitelman syndrome is a a rarely seen autosomal recessive renal tubulopathy characterized by inherited hypokalemic metabolic alkalosis with hypomagnesemia and hypocalciuria. The diagnosis of Gitelman syndrome is usually established during adolescence, but is also observed in childhood and even in the adulthood period. In this case report, we presented a 19-year-old male patient who was diagnosed as Gitelman Syndrome and admitted to the hospital with symptoms of muscle weakness, cramps and weakness.
\end{abstract}

Keywords: Adulthood, Gitelman syndrome, renal tubulopathy

öz

Gitelman sendromu nadir görülen, otozomal resesif kalıtılan, hipomagnezemi ve hipokalsiüri ile birlikte hipokalemik metabolik alkalozla karakterize bir renal tübülopatidir. Gitelman sendromu tanısı genellikle adolesan dönemde konulmakla birlikte çocukluk hatta erişkin dönemde bile gözlenmektedir. Biz bu vaka raporunda kas güçsüzlüğü, kramp ve halsizlik semptomları ile hastaneye başvuran ve Gitelman sendromu tanısı konan 19 yaşındaki erkek hastayı sunduk.

Anahtar kelimeler: Erişkin, Gitelman sendromu, renal tubulopati
Received: 15 October 2018

Accepted: 23 March 2019

Online First: 27 September 2019

Corresponding Author: M. Uzunlulu

ORCID: 0000-0001-8754-1069

Istanbul Medeniyet University Goztepe Training and Researh

Hospital, Department of Internal Medicine, Istanbul, Turkey

mehmet.uzunlulu@medeniyet.edu.tr

B. Dumanoglu ORCID: 0000-0002-4320-2425 Istanbul Medeniyet University Goztepe Training and Researh Hospital, Department of Internal Medicine, Istanbul, Turkey 


\section{INTRODUCTION}

Gitelman syndrome is a rare renal tubulopathy characterized by inherited autosomal recessive, hypokalemic metabolic alkalosis with hypomagnesemia and hypocalciuria ${ }^{1,2}$. Its prevalence is $1-10 / 40.000$, and it is more common in Asia $^{3}$. Gitelman syndrome is one of the most common hereditary renal tubulopathies ${ }^{4}$. In this case report, we presented a male patient who was diagnosed as Gitelman Syndrome and admitted to the hospital with symptoms of muscle weakness, cramps and weakness.

\section{CASE REPORT}

A 19-year-old male patient presented to the hospital with the complaints of muscle weakness, fatigue and cramp. He had no known comorbidities and a history of drug use. On physical examination: turgor tonus was normal, and he was not in a dehydrated state. His blood pressure (100/70 $\mathrm{mmHg}$, pulse rate $(75 / \mathrm{min})$, and respiratory rate $(19 / \mathrm{min})$ were as indicated. Any additional heart sound, murmur, arrhythmia were not detected in cardiovascular system examination, and other system examinations were not remarkable. In the laboratory analyses; the levels of electrolytes were as follows: potassium: $2.8 \mathrm{mEq} / \mathrm{L}$ (normal range 3.5-5.2 mEq/L), magnesium: $1.56 \mathrm{mg} / \mathrm{dL}$ (normal range: $1.7-2.2 \mathrm{mg} / \mathrm{dL}$ ), chloride: $96 \mathrm{mEq} / \mathrm{dL}$ (normal range $98-107 \mathrm{mEq} / \mathrm{dL}$ ). Other laboratory findings of the patient were within normal limits: sodium:140 $\mathrm{mEq} / \mathrm{L}$ (normal range 134-145 $\mathrm{mEq} / \mathrm{L}$ ), phosphorus:3.7 $\mathrm{mg} / \mathrm{dL}$ (normal range 2.6-4.5 mg/dL), creatinine:0.81 mg/dL, urea:34 $\mathrm{mg} / \mathrm{dL}$, albumin:4.9 g/dL, calcium: $10.3 \mathrm{mg} / \mathrm{dL}$, $\mathrm{TSH}: 1.35$ IUI/mL (normal range 0.35-4.94 IUI/ $\mathrm{mL}$ ), parathormone: $24.8 \mathrm{pg} / \mathrm{mL}$ (normal range 11-67 pg/mL), 25 hydroxy vitamin D:14.8 ng/ $\mathrm{mL}$, and cortisol: $14 \mathrm{ug} / \mathrm{dL}$. The patient with compensated metabolic alkalosis as detected in blood gas analysis (pH:7.44, HCO3:30.9 mmol/L) was hospitalized. Then renin $(8.40 \mathrm{ng} / \mathrm{mL} / \mathrm{h}$ :normal range, $0.2-1.6 \mathrm{ng} / \mathrm{mL} / \mathrm{h})$ and aldosterone $(8.27$ $\mathrm{ng} / \mathrm{dL}$ :normal range, 1-16 ng/dL). levels were measured in the blood sample collected with the patient in the supine position. The levels of electrolytes in 24-hour urine were as follows: sodium:136 $\mathrm{mEq} /$ day (normal range $40-220 \mathrm{mEq} /$ day), potassium: $64.8 \mathrm{mEq} /$ day (25-125 mEq/day), chloride $154 \mathrm{mEq} /$ day (normal range 110-250 mEq/day), calcium $<20 \mathrm{mg}$ (normal range 100-300 mg). In renal ultrasonography; the location and size of both kidneys and their parenchymal thickness were within normal limits, contours of the kidneys were regular and increased parenchymal echogenicity in both kidneys was detected. Normotensive patient with hypokalemia, hypomagnesemia, hypochloremia, hypochloremic metabolic alkalosis, hyperreninemia, hypocalciuria was suspected to have diagnosis of Gitelman Syndrome which was also correlated with clinical and laboratory findings. The patient was treated with $613.20 \mathrm{mg}$ of magnesium oxide effervescent tablets once daily and $2.17 \mathrm{~g}$ of potassium citrate and $2.0 \mathrm{~g}$ of potassium bicarbonate once a day, and a diet rich in nutrients with high potassium was recommended. After replacement therapy, it was seen that potassium was $3.5 \mathrm{mEq} / \mathrm{L}$ and magnesium was $1.94 \mathrm{mg} / \mathrm{dL}$.

\section{DISCUSSION}

Gitelman syndrome is characterized by a mutation in the SCL12A3 gene encoding the thiazide-sensitive $\mathrm{Na} / \mathrm{Cl}$ cotransporter in the distal convoluted renal tubuli, resulting in inactivation of this system and more than 350 mutations were identified ${ }^{5,6}$. Gitelman syndrome is treated with free salt intake, potassium-rich diet, oral magnesium and potassium preparations. Differential diagnosis of Gitelman syndrome also includes diuretic and laxative abuse and chronic vomiting. The levels of urine chloride are low in patients with chronic vomiting ( $<25 \mathrm{mEq} / \mathrm{L})$, and diuretic abuse can be ruled out by screening urine levels of implicated drugs ${ }^{7}$. In our case, the patient had no complaints of diarrhea and the levels of chloride was in normal range. 
Bartter syndrome, another cause of familial hypokalemic alkalosis, should also be considered in the differential diagnosis. Bartter syndrome has autosomal recessive inheritance. The main defect is the disorder of sodium reabsorption in the thick segment of loop of Henle ${ }^{8}$. Some forms of the disease have mutations in the $\mathrm{Na}-\mathrm{K}-2 \mathrm{Cl}$ cotransporter or in basolateral chloride channels, and renal outer medullary potassium (ROMK) channel $^{9}$. All of these disorders result in prevention of the absorption of calcium and magnesium in the thick ascending loop of Henle. Magnesium loss is reduced because some of the magnesium is reabsorbed from the distal convoluted tubule. It is usually diagnosed in the first years of life. Polyuria-polydipsia, growth retardation, dehydration, muscle weakness and nephrocalcinosis are detected ${ }^{10}$. Gitelman syndrome can be distinguished from Bartter syndrome by hypocalcaemia and hypomagnesemia, with normal urinary prostaglandin E2 excretion despite increased serum renin activity ${ }^{11}$.

Gitelman syndrome is usually asymptomatic or presents symptoms such as muscle weakness, fatigue, salt craving, thirst, nocturia, constipation, cramps, and carpopedal spasm or tetany episodes triggered by hypomagnesemia ${ }^{12,13}$. In our case, muscle weakness and fatigue were present.

In a consensus report of Improving Global Outcomes (KDIGO) in 2016 for Gitelman syndrome, criteria for suspecting, and refuting diagnosis of Gitelman Syndrome, and identification of biallelic inactivating mutations in SLC12A3 for establishing a diagnosis of Gitelman Sendrome were indicated $^{14}$ (Table 1 ). Our case met the criteria for suspecting but not refuting diagnosis of Gitelman Syndrome. Although the genetic analyses have not been performed in our case, some case reports in the literature also show that diagnosis of Gitelman syndrome can be made with clinical and laboratory tests without genetic testing ${ }^{15-17}$. The diagnosis of Gitelman syndrome is usually made during adolescence, but is also observed in child- hood and even in the adulthood period ${ }^{18}$. We present a 19-year-old male patient in our case, but there were also patients in the literature who were diagnosed with Gitelman syndrome at the age of $60^{19}$.

\section{Table 1. Diagnostic criteria for Gitelman syndrome.}

Criteria for suspecting a diagnosis of Gitelman syndrome Chronic hypokalemia ( $<3.5 \mathrm{mmol} / \mathrm{l})$ with inappropriate renal potassium wasting (spot potassium-creatinine ratio $>2.0$ $\mathrm{mmol} / \mathrm{mmol}$ [ $>18 \mathrm{mmol} / \mathrm{g}]$ )

Metabolic alkalosis

Hypomagnesemia $(<0.7 \mathrm{mmol} / \mathrm{l}[<1.70 \mathrm{mg} / \mathrm{dl}])$ with inappropriate renal magnesium wasting (fractional excretion of magnesium $>4 \%$ )

Hypocalciuria (spot calcium-creatinine ratio $<0.2 \mathrm{mmol} /$ $\mathrm{mmol}[<0.07 \mathrm{mg} / \mathrm{mg}]$ ) in adults.

High plasma renin activity or levels

Fractional excretion of chloride $>0.5 \%$

Low or normal-low blood pressure

Normal renal ultrasound

Features against a diagnosis of Gitelman syndrome

Use of thiazide diuretics or laxatives

Family history of kidney disease transmitted in an autosomal dominant mode

Absence of hypokalemia (unless renal failure); inconsistent hypokalemia in absence of substitutive therapy

Absence of metabolic alkalosis (unless coexisting bicarbonate loss or acid gain)

Low renin values

Urine: low urinary potassium excretion (spot potassium-creatinine ratio $<2.0 \mathrm{mmol} / \mathrm{mmol}[<18 \mathrm{mmol} / \mathrm{g}]$ ); hypercalciuria

Hypertension, manifestations of increased extracellular fluid volume

Renal ultrasound: nephrocalcinosis, nephrolithiasis, unilateral kidneys, cystic kidneys

Prenatal history of polyhydramnios, hyperechogenic kidneys Presentation before age 3 years

Criteria for establishing a diagnosis of Gitelman syndrome Identification of biallelic inactivating mutations in SLC12A3

In conclusion, we report a patient with hypokalemia and hypomagnesemia. Electrolyte imbalance should be considered in patients presented with muscle weakness and fatigue. Gitelman syndrome is usually diagnosed fortuitously in blood test. Physicians will be alert not to miss the diagnosis of Gitelman syndrome.

\section{REFERENCES}

1. Gitelman HJ, Graham JB, Welt LG. A new familial disorder characterized by hypomagnesemia. Trans Assoc Am Physicians. 1966;79:221-35. 
2. Bettinelli A, Bianchetti MG, Girardin E, et al. Use of calcium excretion values to distinguish two forms of primary renal tubular hypokalemic alkalosis: Bartter and Gitelman syndromes. J Pediatr. 1992;120:38-43. [CrossRef]

3. Hsu YJ, Yang SS, Chu NF, Sytwu HK, Cheng CJ, Lin $\mathrm{SH}$. Heterozygous mutations of the sodium chloride cotransporter in Chinese children: prevalence and association with blood pressure. Nephrol Dial Transplant. 2009;24:1170-5. [CrossRef]

4. Knoers NV, Levtchenko EN. Gitelman syndrome. Orphanet J Rare Dis. 2008;3:22. [CrossRef]

5. Simon DB, Nelson-Williams C, Bia MJ, et al. Gitelman's variant of Bartter's syndrome, inherited hypokalaemic alkalosis, is caused by mutations in the thiazide-sensitive $\mathrm{Na}-\mathrm{Cl}$ cotransporter. Nat Genet. 1996;12:24-30. [CrossRef]

6. Takeuchi $\mathrm{Y}$, Mishima E, Shima $\mathrm{H}$, et al. Exonic mutations in the SLC12A3 gene cause exon skipping and remature termination in Gitelman syndrome. J Am Soc Nephrol. 2015;26:1-279. [CrossRef]

7. Gladziwa U, Schwarz R, Gitter AH, et al. Chronic hypokalaemia of adults: Gitelman's syndrome is frequent but classical Bartter's syndrome is rare. Nephrol Dial Transplant. 1995;10:1607-13.

8. Simon DB, Lifton RP. The molecular basis of inherited hypokalemic alkalosis Bartter's and Gitelman's syndrome. Am J Physiol. 1996;271:F961-6. [CrossRef]

9. Herbert SC. Molecular mechanisms. Semin Nephrol. 1999; 19:504-23.
10. Peters $M$, Jeck N, Reinalter S, et al. Clinical presentation of genetically defined patients with hypokalemic salt losing tubulopathies. Am J Med. 2002;112:183-90. [CrossRef]

11. Luthy C, Bettinelli A, Iselin S, et al. Normal prostoglandinuria E2 in Gitelman's syndrome, the hypocalciuric variant of Bartter's syndrome. Am J Kidney Dis. 1995;25:824-8. [CrossRef]

12. Knoers NV. Gitelman syndrome. Adv Chronic Kidney Dis. 2006;13:148-54. [CrossRef]

13. Konrad M, Weber S. Recent advances in molecular genetics of hereditary magnesium-losing disorders. J Am Soc Nephrol. 2003;14:249-60. [CrossRef]

14. Blanchard A, Bockenhauer D, Bolignano D, et al. Gitelman syndrome: consensus and guidance from a Kidney Disease: Improving Global Outcomes (KDIGO) Controversies Conference. Kidney Int. 2017;91:24-33. [CrossRef]

15. Akçakaya $M$, Oymak O, Ünal A, Kavuncuoğlu F, Tokgöz B, Utaş C. Familial Hypokalemic Alkalosis: Gitelman's Syndrome. Türk Nefroloji Diyaliz ve Transplantasyon Dergisi. 2009; 18:97-9.

16. Gül K, Tüzün D, Ersoy R, et al. Şiddetli hipokaleminin nadir bir nedeni: Gitelman Sendromu. İç Hastalıkları Dergisi. 2009;16:190-3.

17. Cotovio P, Silva C, Oliveira N, Costa F. Gitelman syndrome BMJ Case Reports. 2013; pii: bcr2013009095. [CrossRef]

18. Peters $M$, Jeck N, Reinalter $S$, et al. Clinical presentation of genetically defined patients with hypokalemic salt-losing tubulopathies. Am J Med. 2002;112:183-90. [CrossRef] 